\title{
Food purchases: Impacts from the consumers' point of view investigated with a modular LCA
}

\section{Journal Article}

\section{Author(s):}

Jungbluth, Niels; Tietje, Olaf; Scholz, Roland W.

Publication date:

2000

Permanent link:

https://doi.org/10.3929/ethz-b-000423075

Rights / license:

In Copyright - Non-Commercial Use Permitted

Originally published in:

The International Journal of Life Cycle Assessment 5(3), https://doi.org/10.1007/BF02978609 


\title{
Impacts from the Consumers' Point of View Investigated with a Modular LCA
}

\author{
Niels Jungbluth, Olaf Tietje, Roland W. Scholz \\ Natural and Social Science Interface (UNS), Department of Environmental Sciences, ETH Zurich - Swiss Federal Institute \\ of Technology
}

Current address: Zentralstrasse 8, CH-8610 Uster, Switzerland; email: jungbluth@gmx.net, www.uns.umnw.ethz.ch/ jungblu/dis.html

\section{DOI: http:dx.doi.org./10.1065/lca2000.04.026}

Abstract. The goal of this research work was to assist consumers in considering environmental aspects of food consumption. A simplified, modular LCA approach has been used to evaluate the impacts from the consumers' point of view. Comparative LCA's have been calculated for five single aspects of decisions: type of agricultural practice, origin, packaging material, type of preservation, and consumption. The inventory for one module includes the environmental impacts related to one particular product characteristic. The modular LCA allows one to investigate the trade-offs among different decision parameters. It could be shown that most of the decision parameters might have an influence on the overall impact of a vegetable product. Greenhouse production and vegetables transported by air cause the highest surplus environmental impact. For meat products, the agricultural production determines the overall environmental impact. The total impact for vegetable or meat purchases may vary by a factor of eight or two-and-a-half. Different suggestions for consumers have been ranked according to the variation of average impacts, due to a marginal change of behaviour. Avoiding air-transported food products leads to the highest decrease of environmental impacts.

Keywords: Consumers point of view; consumption patterns; decision-making, levels; eco-indicator 95; food, consumption; functional unit, food; marginal change; meat; modular, LCA; LCA, modular; LCA, simplified; purchase; vegetable-

\section{Introduction}

A lot of advice is given to consumers about how to buy environmentally sound products. They should buy fresh organic products from the region, which are available with nearly no packaging. However, in everyday life, many difficult situations exist where a consumer has to decide what is more environmentally sound, e.g. a product from a greenhouse in the region or a product cultivated in open air, but imported from overseas. This research work had the goal of supporting this type of consumer decision.

\subsection{Environmental impacts of food products}

A first choice to consider the relevance of processes in the life cycle is to look at the energy use at different stages of food production and consumption. About two-thirds of the total energy use arises already during the production of food until it reaches the consumer's shopping basket (UtTDENBOGERD et al., 1998). Thus, the production stage and its indirect effects are important when discussing the environmental impacts due to food consumption. About one fourth of the energy use directly takes place during the consumption phase. The remaining energy is used indirectly for the waste management of packages or food residues (UITDENBOGERD et al., 1998).

The extent of environmental impacts of food products depends on various factors, e.g. agricultural technique, transport distance or packaging. It is not easy for consumers or even for experts to account for these impacts (JUNGBLUTH, 1998). Life cycle assessment of food products often focuses on single aspects of products, e.g. agricultural practice (AudsLeY et al., 1997; WeGeNer SLEESWIJK et al., 1996), processing (HøGAAs-EIDE \& OHLSSON, 1998), transport (BÖGE, 1995), or packaging (HABERSATTER et al., 1996; HUNT, 1974; SCHMITZ et al., 1995). Some LCA does exist for single food products that investigate the full life cycle from cradle to grave (ANDERSSON \& OHLSSON, 1999; ANDERSSON et al., 1998; BERNHARD \& Moos, 1998). But, it is generally difficult to generate a summary from these specific LCA studies in order to support consumer decisions.

Research work for a range of food products uses simple indicators, e.g. energy use or greenhouse gas emissions, as a yardstick for the environmental impacts caused (CARLSSONKanyama, 1999; KJer et al., 1994; Kramer et al., 1999; UITDENBOGERD et al., 1998). These indicators, though, cannot fully describe the environmental impacts of agricultural production (JUNGBLUTH, 1998).

Thus, there exists a gap between the very specific LCA studies for single food products and the simplified research work for the comparison of a range of food products. Based on 
these studies, it is difficult to provide a general rule for environmentally relevant decisions while purchasing food products. The aim of this research work is to support consumer decisions and to highlight the characteristics of a product that are most important with respect to a range of environmental impacts.

\subsection{Possibilities for eco friendly behaviour}

In Table 1, we identify the levels of decision-making at which the different actors have possibilities for environmentally relevant decisions. A consumer can decide to shift money from one field of need (e.g. mobility, nourishing) to another. This might be environmentally relevant if one spends, for example, less on travelling, but more on eating in an organic-food restaurant. Within the need field of nourishing one can decide, for example, to eat mainly in fast-food restaurants or to consume only vegetarian food. Closely related is the level of decision among different product groups (vegetables, meat). In one product group (e.g. meat), one can choose to buy more pork or more beef. Decisions within one product category (e.g. cabbage) with different products (e.g. cauliflower, red cabbage, etc.) are very similar. More relevant for consumers are often the choices among variants of a product (e.g. organic or conventionally grown carrots). If the decision has been made for one product, there is still a possibly relevant choice, e.g. for a certain packaging. The consumer can also decide about the processing (e.g. cooling, cooking) of a product in the household. All levels of decision-making are relevant for the overall environmental impacts due to different consumption patterns.

Other actors in the food chain do not have such a variety of environmentally relevant decisions. They are more dependent on the market and on decisions of other actors. Decisions about processing, pre-products or additives are mainly relevant for the producing or processing actors. An ice-cream producer can decide for example about the use of materials, or reduce the amount of energy for production, but he or she normally does not consider producing beer instead of ice cream due to environmental reasons.

At the bottom, the levels of decision-making introduced here use a perspective well known from LCA (e.g. decisions about which pre-products are to be used in processing). At the top, the presentation used takes into account the hierarchy of decisions made by actors. Decisions about different need fields do entail more serious changes than decisions about different variants of a product. Today, energy analysis is used in order to support this type of environmental decision making.

This conceptualisation of decision-making levels differs from other concepts of levels introduced for decision making. SAATY \& VARGAS (1994) distinguished between levels of decision making according to a hierarchical order (e.g. goal of decision, criteria and alternatives) while HUMPHREYS \& BERKELEY (1987) took the time span of decisions into account.

We assume that consumers have the widest range of possibilities open to them to behave in an environmentally sound manner. In this paper, we will focus on the core domain of consumers' decisions while purchasing food products, that is from the level of different product groups down to the level of one product (as marked in Table 1).

\section{Goals and Objectives}

The aim of this research work is to investigate constraints on and options for eco-friendly food purchases by consumers. We chose meat and vegetables for this assessment. These two product groups together account for about $40 \%$ of the toral energy use due to food consumption (JUNGBLUTH, 1998). Two questions are to be answered with this research work:

- What are the possibilities for an ecological behaviour from the consumers' point of view while purchasing food products? The answer should consider all relevant stages in the life cycle, should show a range of environmental impacts relevant for this life cycle, and should be simple enough to be communicable to consumers.

- How far do consumers already realise an environmentally sound behaviour and which constraints for a better ecological behaviour do different consumer subgroups face?

Table 1: Levels of environmental decision making for different actors in the food chain

\begin{tabular}{|c|c|c|c|c|c|}
\hline Farmer & Food-industry & Trader & Consumer & Waste management & Level of decision making \\
\hline & & & & & All need fields (mobility, nourishing, ...) \\
\hline & & & & & One need field (home cooking or restaurant) \\
\hline & & & 5 & & Product groups (vegetables, meat, ...) \\
\hline & & & & & One product group \\
\hline & & & 80 & & Product category (cabbage, salad, ...) \\
\hline & & & & & Variants of a product (organic, conventional) \\
\hline & & & पामापा & & One product (types of packaging, ...) \\
\hline & & & & & Processing \\
\hline & & & & & Pre-product and additives \\
\hline & \multicolumn{5}{|c|}{ The actor can reduce environmental impacts directly. } \\
\hline & \multicolumn{5}{|c|}{ The actor can reduce environmental impacts in co-operation with other actors in the life cycle. } \\
\hline sine & \multicolumn{5}{|c|}{ Levels of decision making considered in this study. } \\
\hline
\end{tabular}




\section{Methods}

\section{1' The modular LCA}

Different determinants of environmental impacts have been identified through a review of over 150 studies that investigate the life cycle of food products (JUNGBLUTH, 2000). Table 2 structures these determinants. Agricultural practice is, for example, one important stage in LCA studies for food products. As shown in Table 2, consumers can recognise the environmental burden by considering product characteristics corresponding to these determinants. The material used for the packaging of a food product determines, for example, the environmental impacts due to the production of the packaging and the waste management for it. Environmental impacts due to transportation can be assessed by the region of origin indicated on the product's packaging. The product characteristics can show different peculiarities, e.g. paper bag as a peculiarity for the characteristic packaging. Table 2 shows the different peculiarities investigated for this study.

Table 2: Determinants of environmental impacts for decisions making levels considered in this study. Corresponding product characteristics for food products and the peculiarities investigated for these characteristics

\begin{tabular}{l|l|l}
\hline \multicolumn{1}{c|}{$\begin{array}{c}\text { Determinants of } \\
\text { environmental impacts }\end{array}$} & \multicolumn{1}{|c}{$\begin{array}{c}\text { Corresponding } \\
\text { product } \\
\text { characteristics }\end{array}$} & \multicolumn{1}{|c}{$\begin{array}{c}\text { Peculiarities } \\
\text { of the } \\
\text { characteristics }\end{array}$} \\
\hline $\begin{array}{l}\text { Type of product and } \\
\text { agricultural practice: (e.g. } \\
\text { organic or greenhouse } \\
\text { production). }\end{array}$ & $\begin{array}{l}\text { Product label, } \\
\text { season, origin, and } \\
\text { product category. }\end{array}$ & $\begin{array}{l}\text { Meat or vegetable } \\
\text { from greenhouse, } \\
\text { organic or other } \\
\text { production. }\end{array}$ \\
\hline $\begin{array}{l}\text { Processing in food } \\
\text { industry and distribution } \\
\text { of the product. }\end{array}$ & $\begin{array}{l}\text { Type of } \\
\text { conservation. }\end{array}$ & $\begin{array}{l}\text { Fresh, chilled, } \\
\text { deep-frozen or } \\
\text { pasteurised. }\end{array}$ \\
\hline $\begin{array}{l}\text { Distance and mode of } \\
\text { transportation. }\end{array}$ & $\begin{array}{l}\text { Country or area of } \\
\text { origin. }\end{array}$ & $\begin{array}{l}\text { Region Berne, } \\
\text { Switzerland, } \\
\text { Europe, overseas. }\end{array}$ \\
\hline $\begin{array}{l}\text { Type and amount of } \\
\text { packaging materials. }\end{array}$ & $\begin{array}{l}\text { Material of the } \\
\text { packaging. }\end{array}$ & $\begin{array}{l}\text { Cardboard, glass, } \\
\text { metal, paper, } \\
\text { plastic, Styropor. }\end{array}$ \\
\hline $\begin{array}{l}\text { Cooling, cooking, etc. } \\
\text { during consumption. }\end{array}$ & $\begin{array}{l}\text { Depending on the } \\
\text { type of conservation } \\
\text { (and household } \\
\text { behaviour). }\end{array}$ & $\begin{array}{l}\text { Fresh, chilled, } \\
\text { deep-frozen or } \\
\text { pasteurised. }\end{array}$ \\
\hline
\end{tabular}

The consumer looking for food in a shop usually encounters various combinations of the product characteristics mentioned in Table 2. Moreover, the consumer may take into account additional characteristics that do not influence environmental impacts (e.g. price or taste).

The LCA for meat and vegetable products has been simplified by using a modular approach. The inventory is split into five modules according to the important characteristics identified in Table 2 . The system boundaries for the inventory of meat and of vegetable purchases are shown in Fig. 1 and Fig. 2, respectively. The inventory for the modules has been calculated for the functional unit of one kilogram of purchased product. The results of the five separate modules can be aggregated to assess the total environmental burden of a purchased product.

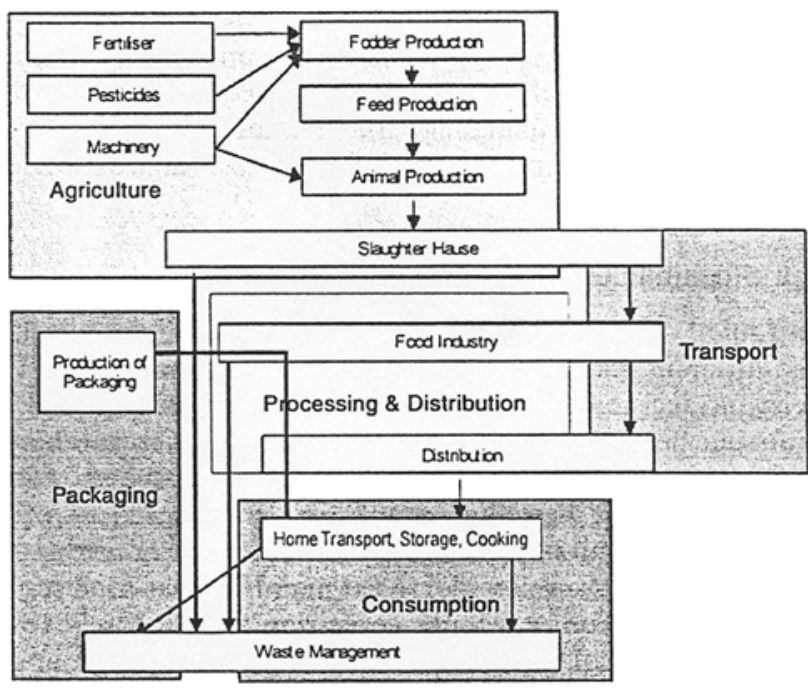

Fig. 1: Life cycle inventory for meat purchases, split up into five modules according to the determinants of environmental impacts and the corresponding product characteristics

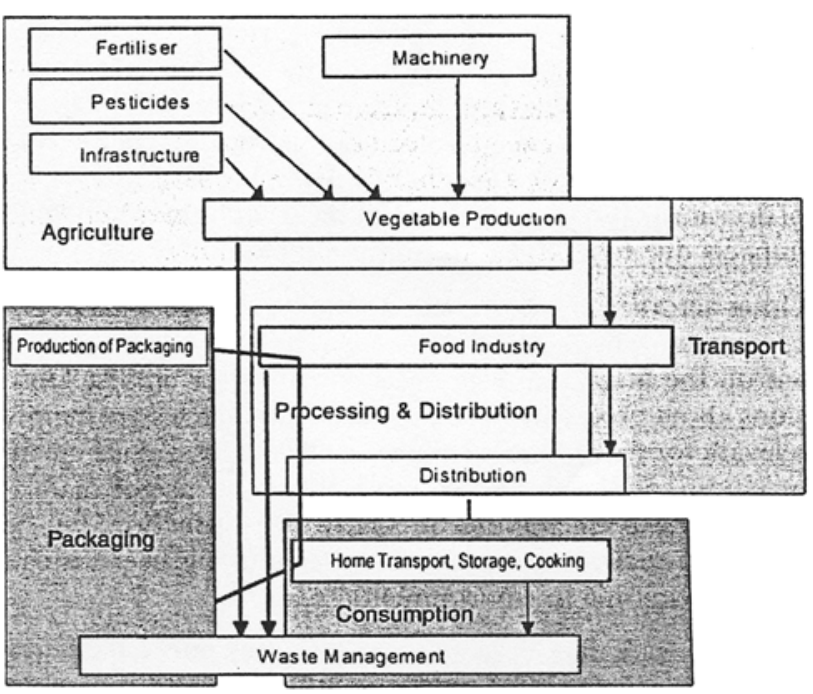

Fig. 2: Life cycle inventory for vegetable purchases, split up into five modules according to the determinants of environmental impacts and the corresponding product characteristics

The inventory for the agricultural production has been modelled both for Swiss integrated (open-air as well as greenhouse) and organic farming for 5 meat and about 15 vegetable products. Data for the use of fertilisers, pesticides and machinery were taken from the Swiss agricultural production inventory (BALTISBERGER et al., 1997, VSGP et al., 1999). Besides the energy related emissions, the inventory also considers emissions of nutrients, pesticides and greenhouse gasses. An average for the product groups of meat and vegetables has been calculated using data on Swiss consumption patterns (Schweizerischer Bauernverband, 1997). Conventional production has been neglected because it becomes more and more unimportant in Switzerland due to policy reasons. Only $35 \%$ of the agricultural area is culti- 
vated in a conventional manner (Schweizerischer Bauernverband, 1997), about $90 \%$ of the vegetables are produced in an integrated way (VSGP et al., 1999), and $12 \%$ of the consumed meat is from integrated or organic production (Schweizerische Genossenschaft für Schlachtvieh- und Fleischversorgung, 1999).

The inventory for the module packaging distinguishes between six and eight common materials used for vegetables and meat, respectively. The life cycle inventory considers the production and the waste management for the packaging that is necessary for one kilogram of a product (HABERSATTER et al., 1996). The environmental impacts due to transports are calculated for four different regions of origin based on the inventory of MAIBACH et al. (1995) and average transport distances (Region: $50 \mathrm{~km}$, Switzerland: $300 \mathrm{~km}$, Europe: $1000 \mathrm{~km}$ and overseas: $12000 \mathrm{~km}$ ).

The processing and distribution of food products is the most difficult to model. Not many LCA studies exist in this field. If they exist, they often do not provide the full details of the inventory due to reasons of secrecy (JUNGBLUTH, 1998). Food processing and distribution are modelled, based on eco-audits of different companies, according to three and, respectively, four different types of meat and vegetable conservation methods.

Environmental impacts of the consumption stage strongly depend on individual behaviour. Thus, they can be calculated only roughly. The inventory for this module considers transport from shop to home, cooling (HOFSTETTER, 1996), cooking (JUNGBLUTH, 1997) management of residues and wastewater (Zimmermann et al., 1996).

The life cycle inventory for the modular LCA has been simplified as far as possible (JUNGBLUTH, 2000). A lot of information has been taken from LCA studies of single food products. These studies have been used to identify the main stages in the life cycle and to gain information on emission factors, allocation procedures, etc. (JUNGBLUTH, 2000). The work of FRISCHKNECHT et al. (1996) has been used as a reference for background data.

\subsection{Impact assessment methods}

The goal for the impact assessment has been to show the impacts in as simple and as accurate a manner as possible while still observing the state of the art in LCA methodology. It has been necessary to use a one-score impact assessment in order to easily compare different product characteristics. Even if the shortcomings of such an approach are widely discussed, it simply docs not seem realistic to compare different impact categories for a wide range of vegetable and meat purchases and to pass this on as information to consumers.

The Eco-indicator 95 (GOEDKOOP, 1995) has been chosen as an appropriate method. It has been extended to include the additional impact categories "radioactive releases" and "use of energy resources" (BRAUnsChweig et al., 1997; MüLlerWENK, 1998). Some corrections have been made for the original characterisation and normalisation values (JUNGBLUTH, 2000). An important change has been the adjustment of the reduction factor for pesticides from 25 to 10 . This means that the importance of pesticides for the valuation is reduced by a factor of 2.5. A characterisation factor for heavy metals, which are emitted into agricultural soil, has been included in the impact assessment (JOLLIET \& CRETTAZ, 1997). This modified method is referred to here as "Ecoindicator 95+". The Swiss method, "Ecological Scarcity" (UBP - Umweltbelastungspunkte), has been used as a second method for valuation (BRAND et al., 1998).

Two requirements of the International Organization for Standardization (1998) for LCA studies could not be fulfilled with this study. Different stages in the life cycle are not assessed in a step by step order, due to the use of a modular approach. The use of a one-score impact assessment for the comparison of different options for environmentally sound behaviour is not supported by the ISO standard.

\section{Results}

\subsection{Life cycle interpretation for the modular LCA for meat and vegetable purchases}

Fig. 3 shows the results for the modules investigated for the purchases of meat. The lower bar in each pair shows Ecoindicator $95+$ points and the upper one the valuation with the ecological-scarcity method. Both impact assessment methods do not differ much as to the general messages for meat products. The overall impact is dominated by the agricultural production. Differences from the consumers' point of view arise mainly from differences among meat from organic and from integrated production. The import of fresh meat from overseas by air adds significantly to environmental impacts. Other product characteristics, such as packaging, conservation method and consumption, are of minor importance.

The impacts of animal production vary by a factor of seven for the different types of meat. Poultry and pork show the lowest impacts while grazing animals show the highest. This point would merit clarification through a full LCA because, from a top-down assessment, it does not seem to make sense to produce more pork instead of meat from grazing animals in Switzerland (AEBERHARD, 1996). The LCA performed

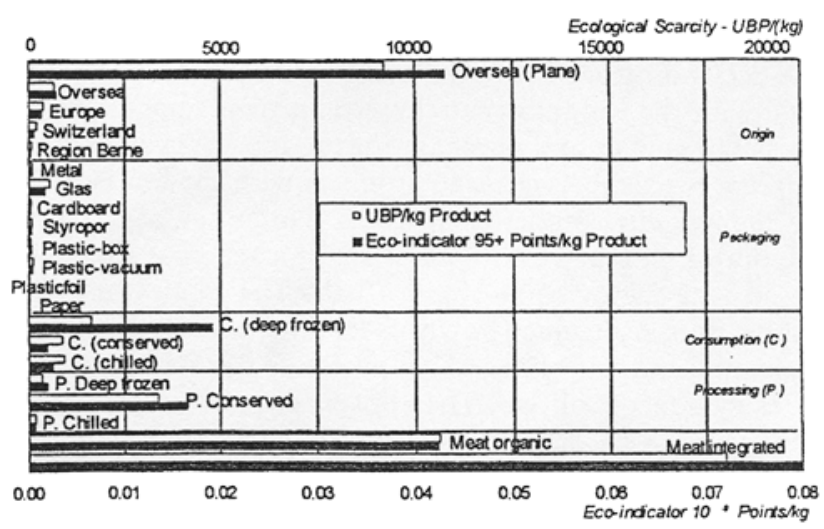

Fig. 3: Eco-indicator 95+ points and ecological scarcity for different peculiarities of characteristics for meat purchases 
here neither does consider the amount and the type of land available nor constraints due to this for different types of animal production.

Fig. 4 shows Eco-indicator $95+$ scores and ecological scarcity points for the different modules investigated for vegetable purchases. In this case, all characteristics make relevant contributions to the environmental impacts of a purchase. The comparison shows somewhat lower scores for organic products compared to products from integrated production. It is important to note that the correctness of this comparison depends on two uncertainties: The inventory for fertilisation and the impact assessment of pesticides.

Greenhouse production has much higher impacts than openair production. The impacts from pasteurisation are higher than those for other conservation measures because the inventory includes $0.11 \mathrm{~kg}$ of agricultural production that goes to waste when producing one kilogram of pasteurised product. This does not happen with fresh or chilled products in the production stage. The consumption stage adds significant impacts to the inventory. The region of production and corresponding transports are important, especially if vegetables are flown in from overseas. Packaging, which has gained a lot of public awareness in the past, does not add much to the total environmental scores (with the exception of a glass jar) and is thus irrelevant to the consumers' decisions (for this example of vegetables).

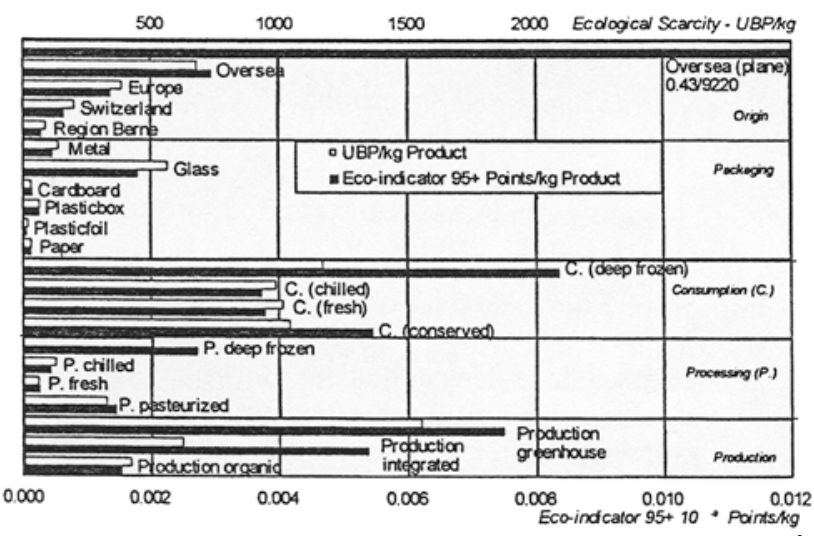

Fig. 4: Eco-indicator 95+ points and ecological scarcity for different peculiarities of characteristics for vegetable purchases.

The Eco-indicator 95+ points calculated here can be multiplied with the weight of purchases and then aggregated to assess the impact of a purchase for the full life cycle. Large differences exist between the products with the lowest and the highest environmental impacts. Purchases of a given amount of meat have environmental impacts that may differ up to a factor of two and a half. The highest impact results from a product flown in from overseas. The environmental burden of vegetable products from Europe can differ by a factor of two. The impacts of products flown in from overseas are eight times higher than those of regionally produced organic vegetables. There is no one strategy to ensure environmental soundness. Thus, as an example, an organic product from Europe might cause higher impacts than one from integrated production in the region.
The importance of the different Eco-indicator 95+ impact categories is shown in Fig. 5. The two right-hand columns show the results for average purchases of meat and of vegetables. The five other columns highlight the impacts due to different forms of agricultural production. The most important impacts in the life cycle of meat products (and animal production) are acidification, nutrification and pesticide use. The use of dung and manure for fertilisation is responsible for this. The uncertainty of this indicator is high due to the variation in fertiliser use among different farms. The ozone-depleting substances used for cooling are also important for an average purchase of vegetables besides the impact categories mentioned for meat. Pesticides dominate the environmental impacts of integrated production in open air with over $70 \%$. The approach used in "Eco-indicator 95+" for this impact category should probably be reconsidered. Other methods, e.g. ecological scarcity (BRAND et al., 1998), give pesticides a much lower weight. Production in greenhouses requires a lot of energy. The environmental impacts are therefore dominated by the impacts from fuel delivery and from combustion.

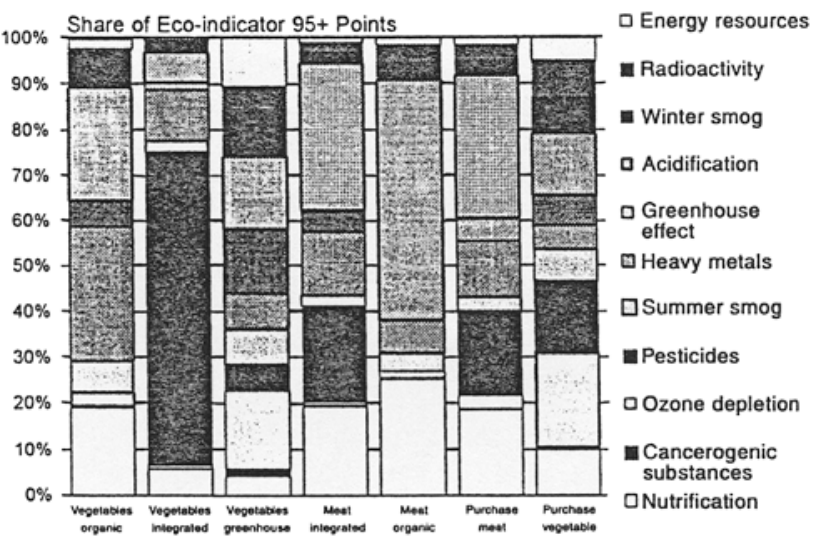

Fig. 5: Share of Eco-indicator 95+ impact categories for agricultural production and average purchases.

\subsection{Environmental impacts of consumption patterns}

People do not only differ in their behaviour, but also in the constraints they face and the available resources. Acknowledging these differences has important implications for the choice of intervention strategies that are to foster environmentally better behaviour. Subgroup differences therefore have to be taken into account. The LCA for meat and for vegetables was used to calculate the environmental impacts of different consumption patterns. A sample of 134 consumers has reported the characteristics of their meat and vegetable purchases in a diary over a period of four weeks ( $A_{R}-$ NOLD et al., 1999; Wolfing-KAST et al., 1999).

These consumers have been classified into six subgroups before (see Table 3) according to predicted determinants of their environmental behaviour, e.g. knowledge, distribution channels used, or importance of environmental values (TANNER et al., 1999).

An average purchase of meat, of vegetables, or of both groups together, has been chosen as the functional unit to compare the environmental impacts due to different consumption pat- 
Table 3: Different types of consumers distinguished for the diary study (TANNER et al., 1999)

\begin{tabular}{|c|c|c|c|c|c|c|}
\hline Description & $\begin{array}{c}\text { Time-short } \\
\text { anti-ecologist }\end{array}$ & $\begin{array}{l}\text { Humane- } \\
\text { supermarket } \\
\text { shopper }\end{array}$ & $\begin{array}{l}\text { Label- } \\
\text { sensitive } \\
\text { shopper }\end{array}$ & $\begin{array}{c}\text { Environmentally } \\
\text { unconscious } \\
\text { regional-product } \\
\text { fan }\end{array}$ & $\begin{array}{l}\text { Imperfect- } \\
\text { ecologist }\end{array}$ & Ideal ecologist \\
\hline Environmental protection & unimportant & unimportant & important & unimportant & important & important \\
\hline Social fairness & unimportant & unimportant & important & unimportant & important & important \\
\hline Regional products & unimportant & important & important & Important & important & important \\
\hline Time orientation & necessary & unimportant & necessary & unimportant & unimportant & unimportant \\
\hline Ecological knowledge & Jow & low & middle & middle & high & high \\
\hline Prediction for ecological purchases & low & low & middle & middle & high & high \\
\hline $\begin{array}{l}\text { Purchasing channels for meat }(\underline{m}) \text { or } \\
\text { vegetables }(\underline{v}): \text { Super = } \\
\text { Supermarket; Small = Small shop; } \\
\text { Org. = Organic shop }\end{array}$ & $\begin{array}{l}\text { m: Super } \\
\underline{\text { v: Super, }} \\
\text { Market }\end{array}$ & $\begin{array}{l}\text { m: Small, Super } \\
\text { v: Super, Market }\end{array}$ & $\begin{array}{l}\text { m: Super } \\
\frac{\mathrm{v}: \text { Super, }}{\text { Market }}\end{array}$ & $\begin{array}{l}\text { m: Small, Super } \\
\text { v: Small, Market, } \\
\text { Super }\end{array}$ & $\begin{array}{l}\text { m: Small, Org. } \\
\text { v: Market, Org., } \\
\text { Super }\end{array}$ & $\begin{array}{l}\text { m: Small, Org. } \\
\text { v: Org., Small, } \\
\text { Market }\end{array}$ \\
\hline 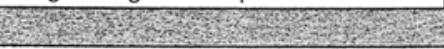 & J & \multicolumn{5}{|c|}{ Constraining factors for ecological purchases } \\
\hline & & \multicolumn{5}{|c|}{ Supporting factors for ecological purchases } \\
\hline
\end{tabular}

terns. Fig. 6 shows the impacts for these consumer subgroups expressed in Eco-indicator 95+ points. The scale for vegetable purchases is on the left side, the one for the total average of meat and vegetable buying on the right side.

Persons belonging to different subgroups do definitely differ with regard to the environmental impacts caused by their purchases. The values of Eco-indicator $95+$ points decrease from the consumer type called "time-short anti-ecologist" to the one named "imperfect ecologist". The comparison shows the predicted environmentally sounder behaviour of those consumers which tend to take the environment more seriously, which have more knowledge, and which use environmentally sounder distribution channels (e.g. organic food stores instead of supermarkets). These consumers considered all the product characteristics and bought those products to a larger extent with the less polluting peculiarities. But, the detailed analysis reveals some constraints on environmentally sound behaviour.

Members of the "label-sensitive" subgroup look mainly at product labels and thus sometimes buy the environmentally more polluting products. Integrated labelling for transport and open air production would be helpful for these labelsensitve persons. It is surprising that the impacts of an average purchase for the "ideal ecologist" are a little bit higher than for the "imperfect ecologist". This is due to the higher amount of meat products purchased by this subgroup even

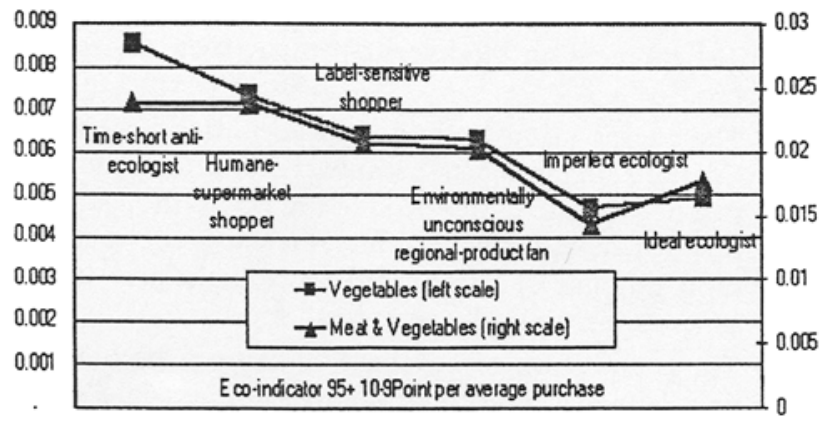

Fig. 6: Eco-indicator 95+ points for an average purchase of different consumer subgroups though these consumers buy meat with an ecological label to a larger extend than these from other groups. This type of consumer may switch to a more vegetarian diet in order to reduce the environmental impact. Arnold et al. (1999) give a more detailed analysis for the different consumer subgroups and their options and constraints for ecological behaviour.

\subsection{Best options for marginal changes in consumption patterns}

Consumers will normally not buy the least polluting products only. However, they can adapt their behaviour and buy more of the environmentally friendly ones. Starting from the average purchases investigated in the diary study, different options for these changes have been compared. Fig. 7 gives the increase or decrease of environmental impacts that result from demanding the indicated peculiarity of a characteristic $1 \%$ more. One can see from the figure that, e.g. if the share of organic products is increased by one percent, the average impact (valued with Eco-indicator 95+) of a vegetable purchase will decline $0.4 \%$. It has been assumed here that the shares of the products with other peculiarities for this characteristic are changed accordingly. A peculiarity whose bar points to the right should be bought less in order to minimise the environmental impacts.

The change in environmental impacts resulting from a marginal change of purchasing patterns helps to rank the different recommendations for consumers. Fig. 7 can be read as a ranking list of the most important strategies for an environmentally sounder behaviour when purchasing vegetables or meat. The highest change for a meat or a vegetable purchase results from avoiding fresh products flown in from overseas. Less than $10 \%$ of the products bought by the consumers in our sample belonged to this category, but they account for over $80 \%$ of the environmental burden due to transportation.

\section{Discussion}

The main goal of the study was to show the relevance of different product characteristics (see Table 2). The modu- 

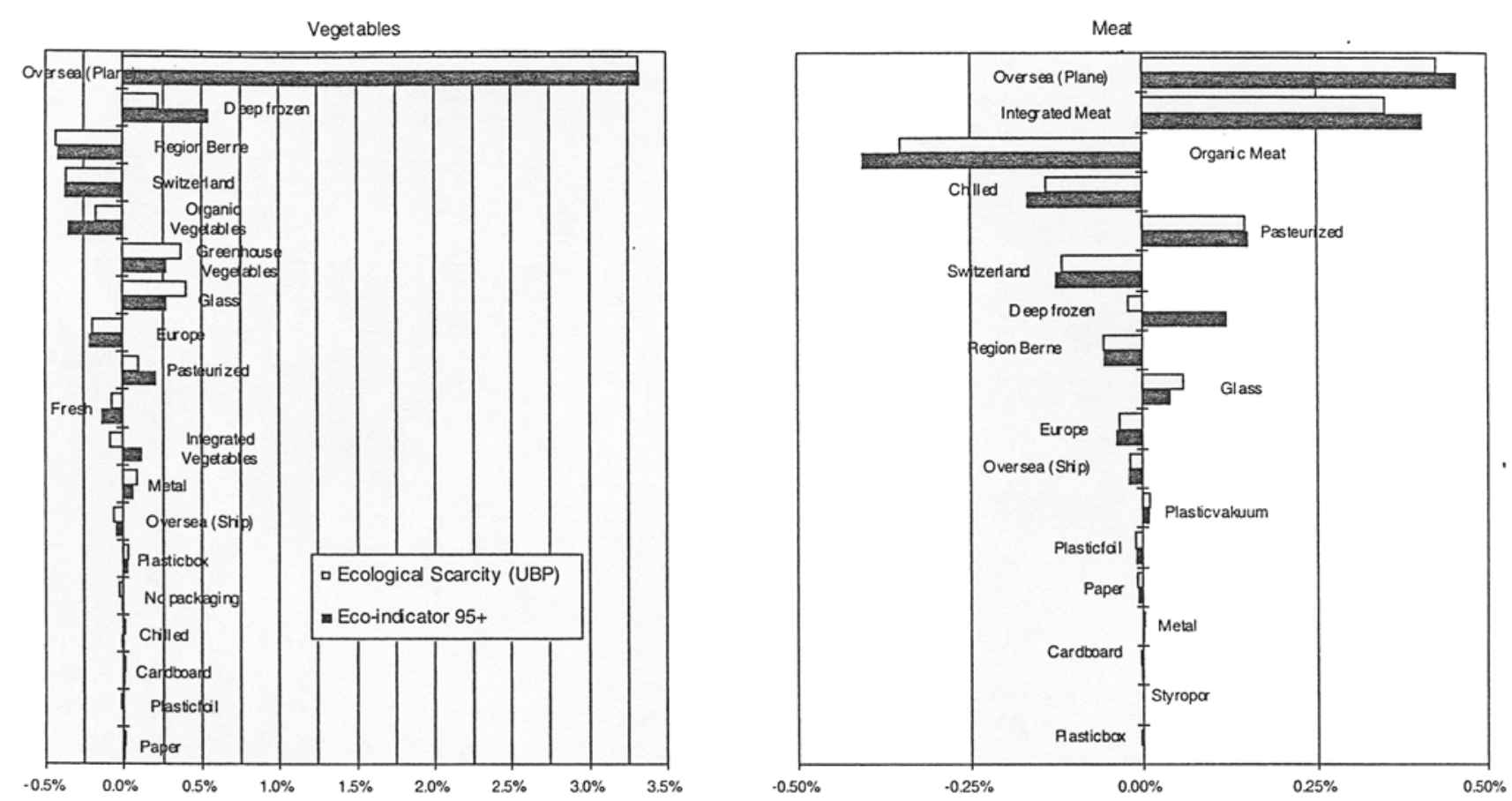

Fig. 7: Change of environmental impacts for food purchases due to a marginal change (1-percentage increase) in the purchase of the products exhibiting the peculiarity shown. Consumers reduce the environmental impacts of their purchases if they buy more products with these peculiarities whose bar point to the left.

lar LCA presented here cannot replace a detailed LCA on specific questions, e.g. the pro and contra of organic production due to the simplifications that have been made for this investigation. The results of this analysis have been checked as far as possible against results from single LCA studies and from studies on the energy use for food production in order to ensure their reliability. LCA for meat products identify the same impact categories as being important as in this study (Møller \& HøgaAs, 1997; Vold \& Møller, 1995). The values found here for the energy use are lower for meat production and about the same order for vegetable production as the figures reported by Kramer \& Moll (1995).

The modular LCA presented here identifies the importance of different product characteristics. The method makes it possible to assess the "environmental behaviour" of persons based on information about their consumption pattern. Moreover, the method simplifies the LCA approach if a range of similar products has to be investigated and if detailed LCA studies can be used to identify hot spots and main inputs to the life cycle.

However, the method presented here has produced new methodological problems due to the simplifications that have been required. Environmental problems are sometimes linked to more than one product characteristic. For example, cooling takes place during transportation for deep-frozen products. Modelling is difficult here, because these impacts depend on the distance of transport and on the type of conservation used. Thus, the modular LCA leads to a new type of allocation problem - the coupling of modules. Not all combinations of product characteristics do exist in reality. One must be careful while interpreting the combined effects. Due to the necessary simplifications of the life cycle inventory, some sources of uncertainty have to be taken into account when interpreting the results:

- The life cycle inventory describes only the agricultural practice in Switzerland. Environmental impacts might vary regionally for single products imported from other countries (Audsley et al., 1997; Probst, 1998; Stadig, 1998).

- The comparison of organic and integrated agricultural production depends on various uncertain assumptions (e.g. inventory for fertiliser use and impact assessment for pesticides). Detailed LCAs also do not give a unique picture of the type of production that is the more environmentally sound one (JUNGBLUTH, 2000). Thus, the results presented here cannot be generalised in support of an organic agricultural production.

- Some environmental impacts that are important for agricultural production have not been taken into account with the valuation methods used here (e.g. land and water use, impacts on biodiversity, impacts on the resource "soil").

- The conservation method "pasteurisation" shows considerable high impacts because the inventory includes a surplus of agricultural production that is thought necessary for manufacturing. But, one can assume that the same amount of pasteurised food might give the consumer a higher utility than fresh food.

- The comparison of purchases based on the functional unit defined as one kilogram does not take into account qualitative differences between different products that do not deliver the same utility. This is especially impor- 
tant when investigating the differences between diets with or without meat.

- It has to be taken into account that agricultural production can not be transformed into all directions. It is, for example, impossible to produce vegetables or fodder in alpine regions where you today have animals (cows or sheep) grazing in the summertime.

\section{Conclusions}

Consumers have the chance to reduce the environmental impacts significantly due to their food purchases. The investigation of meat and vegetable purchases shows that different product characteristics have to be taken into account if one wants to achieve this goal. The inventory presented enables consumers to evaluate the environmental impacts of a number of specific options when purchasing vegetables and meat. ${ }^{1}$ The following conclusions can be drawn from the modular LCA:

- Large differences exist between the products with the lowest and the highest environmental impact. Purchases of a certain amount of meat or vegetables may differ by a factor of 2.5 or of 8 , respectively, in the environmental impacts they cause.

- The most important options for a reduction of environmental impacts are the refusal of air-transported products, a preference for organic products and a reduction in meat consumption.

- Packaging is of minor importance, for both vegetables and meat. However, results for one product group might not hold true for another one (e.g. beverages) with another life cycle.

- The environmentally important product characteristics of air transport and of greenhouse production are not easy to identify by the consumers. These characteristics should therefore be declared on the product or be integrated in existing guidelines for labels.

\section{Future Research Questions}

The modular LCA can be used to identify questions for detailed LCA studies. The simplified LCA reveals large differences even for vegetables belonging to the same product category (e.g. Brussels sprouts and red cabbage) and for different types of meat. A comparison for a range of meat or vegetable products would be an interesting question for a detailed LCA. The definition of a good functional unit for the comparison of different food products should also be addressed in further research work.

The focus on different levels of decision-making might help to evaluate the importance of specific LCA findings. It seems to be useful to distinguish the environmental relevance of different decision possibilities. Empirical research might clarify how far different actors already recognise these different levels of decision making. LCA might also help to identify the significance of these different levels for the adop-

' Some of the results have been made available for consumers in a calculation tool on www.uime.uns. umnw.ethz.ch (EPP \& REICHENBACH, 1999). tion of ecological behaviour. In addition, consumer research might figure out if consumers (can) take into account additional product characteristics that are important with respect to the environmental impacts they cause.

Acknowledgements. This work was part of a Ph.D. project financed by the Swiss National Science Foundation within the Priority Programme Environment.Thanks go to Stephan Arnold, Sybille WölfingKast, Carmen Tanner and Karin Saetteli, University of Bern, for the provision of data and their helpful co-operation within the diary study. We thank Thomas Köliner for his useful comments on previous versions of this manuscript, and Thomas Baumgartner for comments on the English language.

\section{References}

Aeberhard, T. (10.1996): Nachhaltiger Konsum von Fleisch und anderen tierischen Produkten. Konsum \& Umwelt, WWF Schweiz, Zürich

Andersson, K., Ohlsson, T. (1999): Life Cycle Assessment of Bread Produced on Different Scales. In Int. J. LCA Vol. 4 (1): 25-40, Landsberg, Germany

Andersson, K.; Ohlsson, T., Olsson, P. (1998): Screening life cycle assessment (LCA) of tomato ketchup: a case study. In Journal of Cleaner Production Vol. 6 (3-4): 277-288

Arnold, S.; Tanner, C., Wölfing-Kast, S. (3.1999): Die Wirkung ausgewählter Kontextbedingungen auf das ökologisch nachhaltige Einkaufsverhalten: Resultate einer Tagebuchstudie. Forschungsbericht No. 4, Psychologischen Institut, Universität Bern, Switzerland

Audsley, E.; Alber, S.; Cowell, S. J.; Clift, R.; Crettaz, P.; Gall.ard, G.; Hausheer, J.; Jolliet, O.; Klejun, R.; Mortensen, B.; Paarce, D.; Roger, E.; Teulon, H.; WeidemA, B., Ziejts, H. v. (6.1997): Harmonisation of Environmental LCA for Agriculture. Final Report, Concerted Action No. AIR3-CT94-2028, Silsoe Research Institute, Silsoe, Great Britain

Baltisberger, F.; Honegger, U.; Meyer, A.; Rahmen, K., Todt, W. (1997): Deckungsbeiträge - Ausgabe 1997 1. Disketten (2) for DOS - Excel, Landwirtschaftliche Beratungszentrale Lindau (LBL), Switzerland

Bernhard, S., Moos, T. (12.1998): Ökobilanz des Camembert: Entscheidungsgrundlagen für den umweltbewussten Einkauf von Weichkäse. FAU-Schriftenreihe, Fachverein Arbeit und Umwelt, Zürich

BOGE, S. (1995): Erfassung und Bewertung von Transportvorgängen: Die produktbezogene Transportkettenanalyse. In Läpple, D.: Güterverkehr, Logistik und Umwelt, Analysen und Konzepte zum interregionalen und städtischen Verkehr. Vol. 2. überarbeitete und erweiterte Auflage, Pages: 113 - 141, sigma Verlag, ISBN/ISSN 389404-352-0, Berlin

Brand, G.; Scheidegger, A.; Schwank, O., Braunscinweig, A. (1998): Bewertung in Ökobilanzen mit der Methode der ökologischen Knappheit - Ökofaktoren 1997. Schriftenreihe Umwelt No. 297, INFRAS, Bundesamt für Umwelt, Wald und Landschaft (BUWAL), Bern

Braunschweig, A.; Brunner, S.; Hofstetter, P., Müller-Wenk, R. (UNPUBLISHED-1997): Umweltliche Bewertung im Automobilbau - Einführung und Weiterentwicklung des Eco-Indicator 95. Auftrag der Daimler-Benz AG, Abt. EP/VUG Umweltnatur- und Umweltsozialwissenschaften (UNS), Institut für Wirtschaft und Ökologie, Eidgenössische Technische Hochschule, Universität St. Gallen, Zürich, St. Gallen

Carlsson-Kanyama, A. (1999): Consumption Patterns and Climate Change: Consequences of eating and travelling in Sweden. Doctoral Thesis, Department of System Ecology, Stockholm University, Sweden EPP, A., REICHENBACH, A. (8.1999): Rückmeldung an KonsumentInnen zu den Umweltfolgen ihrer Lebensmitteleinkäufe. Diplomarbeit Nr. 
26/99, Umweltnatur- und Umweltsozialwissenschaften, Eidgenössische Technische Hochschule, 147 Pages, www.ulme.uns.umnw. ethz.ch, Zürich

Frischinecht, R.; Bollens, U.; Bosshart, S.; Ciot, M.; CiserI, L.; Doka, G.; Dones, R.; Gantner, U.; Hirschier, R., Martin, A. (1996): Ökoinventare von Energiesystemen. Grundlagen für den ökologischen Vergleich von Encrgicsystemen und den Einbezug von Energiesystemen in Ökobilanzen für die Schweiz. Auflage No. 3, Gruppe Energie - Stoffc - Umwelt (ESU), Eidgenössische Technische Hochschule Zürich und Sektion Ganzheitliche Systemanalysen, Paul Scherrer Institut Villingen/Würenlingen, Switzerland

GoEDKOOP, M. (1995): The Eco-indicator 95 - Weighting method for environmental effects that damage ecosystems or human health on a European scale. Final Report Novem, rivm, Amersfoort

HabersatTer, K.; Fecker, I.; Dall'ACqua, S.; Fawer, M.; Fallscheeer, F.; Fórster, R.; Malllefer, C.; Menard, M.; Reusser, L., Som, C. (1996): Ökoinventare für Verpackungen. Schriftenreihe Umwelt No. 250, Bundesamt für Umwelt, Wald und Landschaft, Bern, Switzerland

HöSTETTER, P. (6.1996): Ökobilanz Ökokühlschrank - Ein Vergleich von Kühlschränken traditioneller Bauart mit verschiedenen hochwärmegedämmten Varianten. Kurzstudie Büro für Analyse \& Oekologie, Zürich, Switzerland

HøgaAs-Eide, M., OHLsson, T. (1998): A Comparison of Two Different Approaches to Inventory Analysis of Dairies. In Int. J. LCA Vol. 3 (4): 209-215, Landsberg, Germany

Humphreys, P., Berkfeley, D. (1987): Problem structuring calculi and levels of knowledge representation in decision making. In Scholz, $\mathrm{R}$. W.: Decision Making under Uncertainty. Vol. 16, Pages: 121-157, Advances in Psychology, North-Holland, Amsterdam

Hunt, R. G. E. A. (1974): Resource and Environmental Profile Analysis of Nine Beverage Container Alternatives. Midwest Research Institute for U.S. Environmental Protection Agency, Washington D.C.

INTERNATIONAL ORGanization for Standardization (ISO) (6.1998): Environmental Management - Life Cycle Assessment. Final Drafts from working groups for the set up of standard ISO $14040 \mathrm{ff}$, Paris

JOLliet, O., CretTAZ, P. (1997): Assessment of Human Toxicity in Life Cycle Assessment, including fate and exposure: the critical surfacetime method. In Int. J. of Risk Analysis (submitted), New York, London

JUNGBLUTH, N. (8.1997): Life-Cycle-Assessment for Stoves and Ovens. UNS-Working Paper No. 16, Umweltnatur- und Unweltsozialwissenschaften (UNS), Eidgenössische Technische Hochschule, Zürich

JUNGBLUTH, N. (8.1998): Ökologische Beurteilung des Bedürfnisfeldes Ernährung: Arbeitsgruppen - Methoden - Stand der Forschung Folgerungen. Working Paper No. 18, Umweltnatur- und Umweltsozialwissenschaften, Eidgenössische Technische Hochschule, www.uns. umnw.ethz.ch/ -jungblu/publication.html, Zürich

JUNGBLUTH, N. (2000): Umweltfolgen des Nahrungsmittelkonsums: Beurteilung von Produktmerkmalen auf Grundlage einer modularen Ökobilanz. Dissertation Eidgenössische Technische Hochschule Zürich Nr. 13499, Umweltnatur- und Umweltsozialwissenschaften, dissertation.de, ISBN/ISSN 3-89825-045-8, Pages: 317, www.uns. umnw.ethz.ch/-jungblu/dis.html, Berlin

KJeR, I.; Simon, K. H.; ZeHR, M.; ZeRger, U.; KasPar, F.; Bossel, H.; Meier-Ploeger, A., Vogtmann, H. (1994): Landwirtschaft und Ernährung. In Enquete-Kommission "Schutz der Erdatmosphäre": Landwirtschaft - Studienprogramm. Vol. Band I, Teilband II, Studie J, Economica Verlag, Bonn

KRAMER, K. J., MolL, H. C. (1995): Energie voedt: nadere analyses van het indirecte energieverbruik van voeding. Final report to the NRP global Air Pollution and Global Change, IVEM research report No. 77, Center for Energy and Environmental Studies of the University of Groningen (IVEM RUG), The Netherlands

Kramer, K. J.; Moll, H. C., Nonhebel, S. (1999): Greenhouse gas emissions related to Dutch food consumption. In Energy Policy Vol. 27 (4): 203-216, Great Britain

Maibach, M.; Peter, D., SeILER, B. (12.1995): Ökoinventar Transporte - Grundlagen für den ökologischen Vergleich von Transportsystemen und den Einbezug von Transportsystemen in Ökobilanzen. Technischer Schlussbericht, Auftrag No. 5001-34730, ISBN 3-95208245-7, INFRAS, Zürich

MølıER, H., HøGAAs, M. (30.6.1997): Livsløpsanalyse ved produksjon av kjøtt og melk: en vurdering av kombinert melk/kjettproduksjon og selvrekrutterende kjottproduksjon. Oppdragsrapport No. OR. 53.97, Norsk Kjøtt, v/ Kjetil Toresen, Oslo, Norway

MüLIER-WenK, R. (1998): Depletion of Abiotic Resources Weighted on Base of "Virtual" Impacts of Lower Grade Deposits Used in Future. IWÖ - Diskussionsbeitrag No. 57, Inst. f. Wirtschaft und Ökologie, Hochschule St. Gallen, Switzerland

Próst, B. (10.1998): Ökologische Beurteilung unterschiedlicher Produktionssysteme von Brot unter besonderer Berücksichtigung Regionaler Produktion: Ein Vergleich auf Basis der Ökobilanzierung. Diplomarbeit, Philosophisch-naturwissenschaftliche Fakultät, Universität Bern, 163 Bern

SaATY, T. L., VarGas, L. G. (1994): Decision Making in Economic, Political, Social and Technological Environments. The Analytic Hierarchy Process Series, RWS Publications, ISBN/ISSN 0-9620317-71, Ed. 1, Pages: 330, Pittsburgh

Schmitz, S.; Oels, H.-J., TiedemanN, A. (8.1995): Ökobilanz für Getränkeverpackungen. Texte No. 52/95, Umweltbundesamt, Berlin

Schweizerische Genossenschaft für Schlachtvieh- Und FleischverSORGUNG (1999): Jahresbericht 1998: Der Fleischmarkt in Überblick. GSF, Bern

SCHWEizerisCher Bauernverband (1997): Statistische Erhebungen und Schätzungen - über Landwirtschaft und Ernährung 1996. Abt. Statistik, Brugg

STADIG, M. (1998): Life-cycle-assessment of apple production in Sweden, New Zealand and France. The Swedish Inst. for Food and Biotechnology, Göteborg

TANNER, C.; WOl.FING-Kast, S., ARnold, S. (3.1999): Typisierung von Konsumenten und Konsumentinnen aufgrund personaler und verhaltensbezogener Unterschiede. Forschungsbericht No. 2, Psychologischen Institut, Universität Bern, Switzerland

UtTdenbogerd, D. E.; Brouwer, N. M., Groot-Marcus, J. P. (1998): Domestic energy saving potentials for food and textiles - An empirical study. H\&C oderzoeksrapport, Department of Household and Consumer Studies, Wageningen Agricultural University, Wageningen

Volo, M., Møller, H. (21.11.1995): Livsløpsanalyse ved Kjøttproduksjon - en vurdering av svine- og lammekjøttproduksjon. Oppdragsrapport No. OR. 53.95, Stiftelsen estfoldforskning, Godkjent, Norway

VSGP; Kommission für Produktionskostenberechnung; SchweizeRisCHe ZeNtralstelle fur GemÓsebau (SZG), Forschungsinstitut Für biologischen Landbau (FIBL) (8.1999): Berechnung der Produktionskosten von Gemüsearten 1999. Koppigen

WeGener SleeswiJk, A.; Kleijn, R.; Zeijts, H. v.; Reus, J. A. W. A.; Meeusen-van Onna, M. J. G.; Leneman, H., Sengers, H. H. W. J. M. (1996): Application of LCA to Agricultural Products. CML report No. 130, Centre of Environmental Science (CML), Centre of Agriculture and Environment (CLM), Agricultural-Economic Institute (LEI-DLO), Leiden

WÖlfing-KaST, S.; TANNER, C., ARNoLd, S. (3.1999): Die Wahrnehmung von handlungsrelevanten Informationen für ein ökologisch nachhaltiges Einkaufsverhalten durch verschiedene Konsumtypen. Forschungsbericht No. 3, Psychologischen Institut, Universität Bern, Switzerland

Zimmermann, P.; Doka, G.; Huber, F.; Labhardt, A., Mènard, M. (1996): Ökoinventare von Entsorgungsprozessen. Grundlagen zur Integration der Entsorgung in Ökobilanzen. ESU-Reihe No. 1/96, Inst. f. Energietechnik, Gruppe Energie - Stoffe - Umwelt (ESU), Eidgenössische Technische Hochschule Zürich, Switzerland

Received: October 18th, 1999 Accepted: March 3rd, 2000 Online-First: April 20, 2000 